\title{
Urban Sprawl and its Impact on Urbanization in Raipur City (Chhattisgarh State), India
}

\author{
Rajib Jana ${ }^{1 *}$, Anil Kumar Sinha²
}

\begin{abstract}
${ }^{1}$ Research Scholar (Geography), Sant Gahira Guru Vishwavidyalaya Sarguja Ambikapur (Chhattisgarh State), India. ${ }^{2}$ Assistant Professor
\end{abstract} (Geography), at present NSS Programme Co-ordinator, Sant Gahira Guru Vishwavidyalaya Sarguja Ambikapur (Chhattisgarh State), India.

\begin{abstract}
A city is an outcome of physical growth process, reflects man's efforts and achievements in shaping his environment during the entire period of its development so, the capital city Raipur of Chhattisgarh state being no exception. This area is extended from 21 14 ' 14 "N latitudes to 8138 ' 5 "E longitudes. As of the 2011 registration, Raipur municipal corporation had a population is $1,010,087$ persons. The present research paper is based on both the primary data which is collected through LANDSAT Satellite as well as field survey and secondary data is acquired from the Master plan of Raipur city, top sheet and Census of India - Primary Census Abstract respectively. These research paper is an attempt to analysis the trends of urban sprawl areas and its impact on urbanization in Raipur city. Remote sensing and GIS techniques are used to analyze the urban sprawl scenario, mapping and detect the changing pattern of urban sprawl areas of Raipur city through different time period. In Raipur city the expanding of urban sprawl areas are positively increased 29.86 sq.km. from 1971-1981 to 1981-1991, 9.26 sq.km. from 1981-1991 to 1991-2001, 6.18 sq.km. from 1991-2001 to 2001-2011 and 6.37 sq.km. from 2001-2011 to 2011-2018 which is positively impact on rapid growth of urbanization. The expanding of study area is very fast in almost in all direction from city centre and it is observed that its urban sprawl areas increased continuously day by day due to rapid growth of urban population. The positive relationship is found in between urban sprawl and urbanization.
\end{abstract}

Key words: Raipur city, Urban Sprawl, Residential areas, rapid growth of population and Urbanization.

\section{INTRODUCTION}

The current trends of urban growth has the most obvious environmental impacts on the surrounding ecosystems, land resources, structure and pattern of the urban area and hence quality of life $(1,2)$. The concept urban sprawl is one of the most important phenomena of a city with particular reference to undergoing rapidly growth of urbanization processes. The urban Sprawls are remarkable concentrated at the periphery regions of a city in the form of radial pattern and it is rapidly increase along the highways as well as major roads with the elongated urban development (3-5). Urban sprawl is a significant concept with reference to growth of a city from centre to fringe area. Development of urban sprawl areas is patchy, scattered and sprung out, with a tendency to discontinuity because it leap-frogs over some areas in
Raipur city. The shape, size and direction of growth of Raipur city are the result of different factors, such as physical, economical and social which have played a significant role in its development. An urban morphological point of views, the urban sprawl is most important thing which is greatly effects on urban development due to increasing pattern of urban population as well as socio-economic conditions of a city. Cities in many parts of the world are facing issues of excessive growth which leads to one of its notorious problem, namely urban sprawl (6-9). The capital city Raipur of Chhattisgarh state is an outcome of physical growth process and reflects man's efforts and achievements in shaping his environment during the entire period of its development.

*Address of Correspondence: Rajib Jana, Research Scholar (Geography), Sant Gahira Guru Vishwavidyalaya Sarguja Ambikapur (Chhattisgarh State), India. E-mail- rajibgeo1990@gmail.com 


\section{STUDY AREA (RAIPUR CITY)}

Raipur city is located in the middle part of Chhattisgarh State. Study area Raipur city is situated in the heart of Chhattisgarh state (Rice Bowl). Study area is extended from $2114^{\prime} 14^{\prime \prime} \mathrm{N}$ latitudes to $8138^{\prime}$ 5 "E longitudes. The total geographical areas of the study area are 326 sq.km. As per the census 2011- the total population of Raipur city is 10.1 lakhs and total number of municipal corporation wards is 70. Raipur city is an important junction on the Mumbai-Kolkata trunk line of the south eastern Centre railway lines; enjoy a Centre location in the Chhattisgarh sate. The site of Raipur is a low ridge on the north-east of the Kharun river. Raipur city is the premier city and the

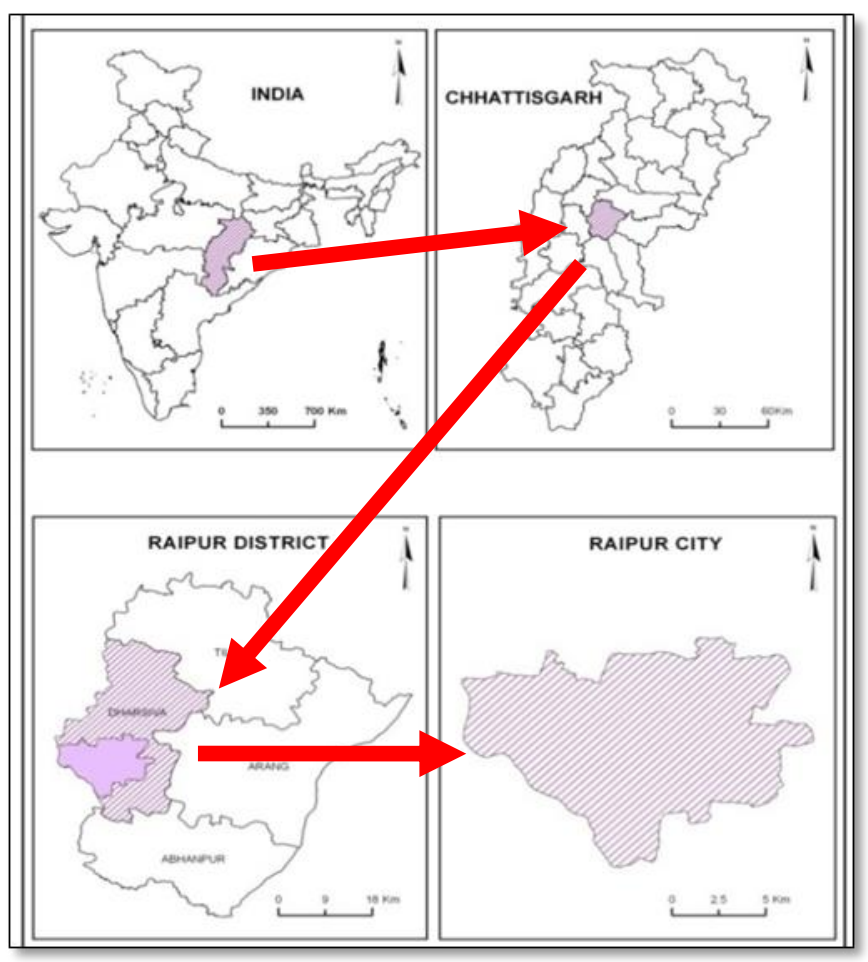

Figure no 1: Location Map of Study Area

\section{OBJECTIVES}

The main objectives of the present study are as follows:

(i) To analysis the trends of urban sprawl areas and its impact on Urbanization in Raipur city.

(ii) To find out the changing pattern of urban sprawl areas as well as change detection of urban sprawl boundary of Raipur city through different observation years. capital city of the Chhattisgarh state, is an important administrative, commercial, industrial, and educational Centre. The established of Bhilai steel plant in close proximity has given a great impetus to growth and its nodal location has contributed to its growing importance. Raipur city lies at the convergence of numerous roads, national highway no.6 Joining Kolkata and Mumbai runs through the city. The city has an altitude of $298.15 \mathrm{mt}$. above the mean sea level. Urban sprawl areas are remarkable concentrated with particular reference to the growth of a Raipur city.

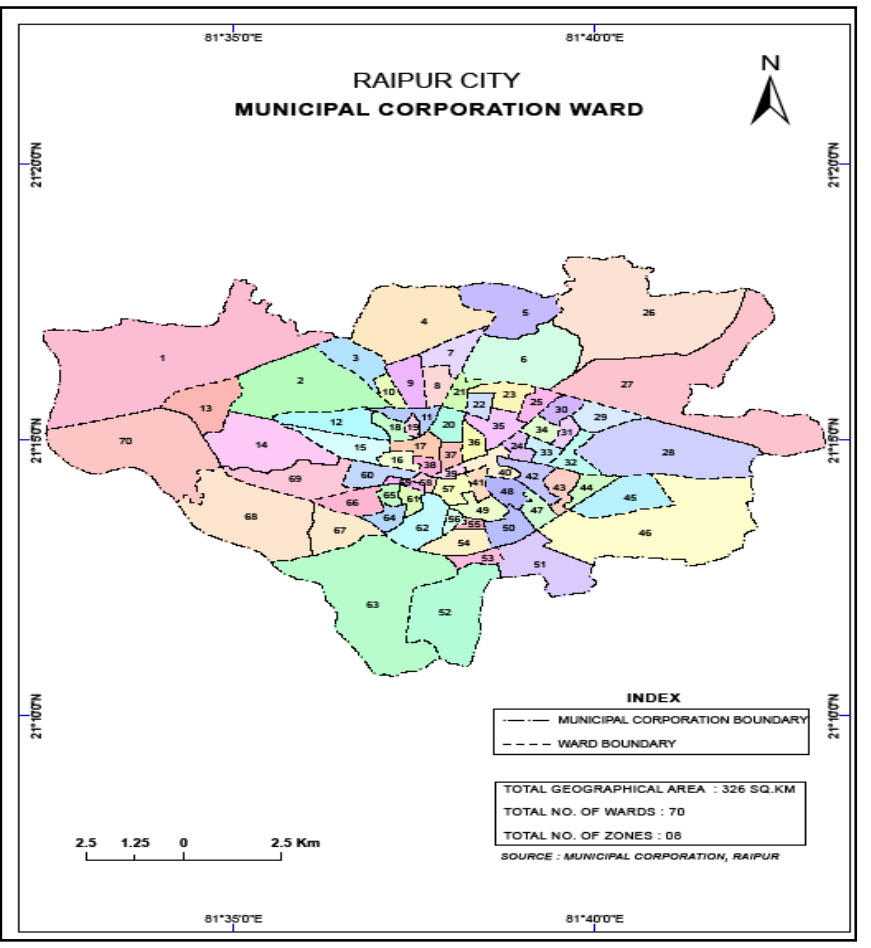

Figure no 2: Municipal Boundary of Raipur City

(iii) To analyze the causes of rapidly expanding of Urban sprawl or suburban sprawl areas in Raipur city. 
RJ and AKS

\section{SOURCES OF DATA, DATA COLLECTION AND RESEARCH METHODOLOGY}

The present research paper is based on both the primary data and secondary data.

- Satellite data: LANDSAT TM and LANDSAT ETM+ , LANDSAT MSS images

- $\quad$ Field Survey

- Master Plan of Raipur city

- $\quad$ Top Sheet (Survey of India): R.F. 1:25000
Original article

- Census of India - Primary Census Abstract

To analyze the urban sprawl scenario, cartographic representation, change detection of urban sprawl boundary of Raipur city and detect the changing pattern of urban sprawl areas and its impact on urbanization in Raipur city through different time periods, is based on the methodology of Remote sensing and GIS techniques with the help of satellite imagery of Raipur city to give a visual look for the present study.

Primary and

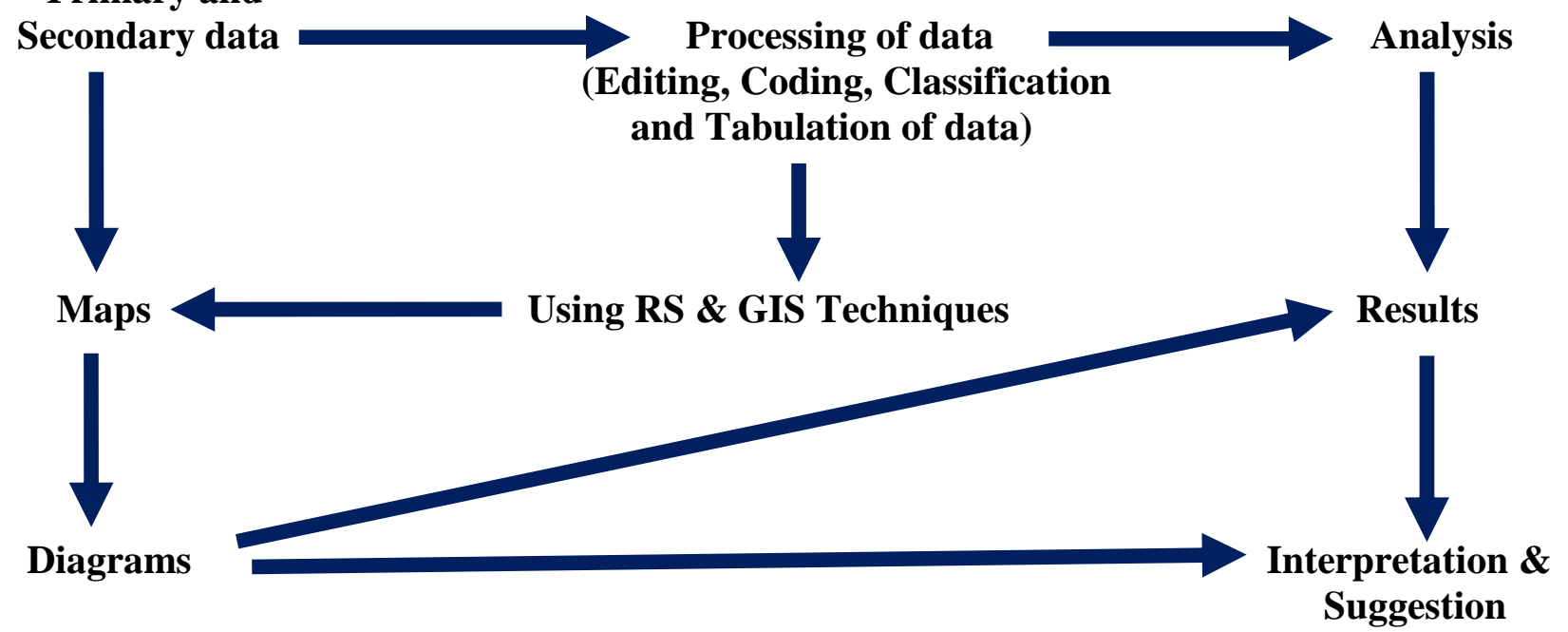

RS $=$ Remote Sensing

GIS = Geographical Information System

Figure no 3: Flow Chat of Sources of Data, Data Collection and Research Methodology

\section{RESULTS}

\section{Changing Pattern of Urban Sprawl Areas in Raipur}

City: The table no.1 \& figure no.4 Showing, in Raipur city the expanding of urban sprawl areas are positively increased 29.86 sq.km.in the study years from 19711981 to $1981-1991,9.26$ sq.km.in the study years from 1981-1991 to $1991-2001,6.18$ sq.km.in the study years from 1991-2001 to 2001-2011, 6.37 sq.km.in the study years from 2001-2011 to 20112018 which is positively impact on rapid growth of urbanization. In Raipur city the changing pattern of urban sprawl areas are mainly caused by different factors, such as - Positive impacts of Macro-Economic factors, Micro-Economic factors, Demographic characteristics of a city, Housing Preferences, Inner city problems, Transportation system and Regulatory frameworks of a City.

The figure no. 4 showing the changing pattern of urban sprawl areas in Raipur city. The development of urban sprawl areas is mainly concentrated in C.B.D. zones from 1971 up to 1976 due to central location of Raipur city, employment opportunities and Raipur city is an important junction of south eastern Centre railway line etc. In the observation years from 1976 to 1998, the development of urban sprawl areas are found outsides the C.B.D. zones which is gradually increased towards the fringe areas due to rapid growth of urban population. In the observation years from 1998 to 2011, the development of urban sprawl areas are highly concentrated on fringe areas in 
RJ and AKS

almost all direction from C.B.D. zones due to Raipur becoming a Capital city of Chhattisgarh state, rapid growth of urban population, immigration and Raipur

\section{Original article}

lies at the convergence of numerous roads, National Highways and south eastern Central railway line.

Table no 1: Showing the Changing Pattern of Urban Sprawl Areas in Raipur City

\begin{tabular}{|c|c|c|c|c|}
\hline $\begin{array}{c}\text { Study } \\
\text { Years }\end{array}$ & $\begin{array}{c}(1971-1981) \\
\text { To } \\
(1981-1991)\end{array}$ & $\begin{array}{c}(1981-1991) \\
\text { To }\end{array}$ & $\begin{array}{c}(1991-2001) \\
\text { To }\end{array}$ & $\begin{array}{c}(2001-2011) \\
\text { To }\end{array}$ \\
\hline $\begin{array}{c}\text { Changing Pattern } \\
\text { of Urban Sprawl } \\
\text { Areas (Sq. Km.) }\end{array}$ & 29.86 & 9.26 & 6.18 & 6.37 \\
\hline
\end{tabular}

\section{Sources: - LANDSAT Satellite Data}

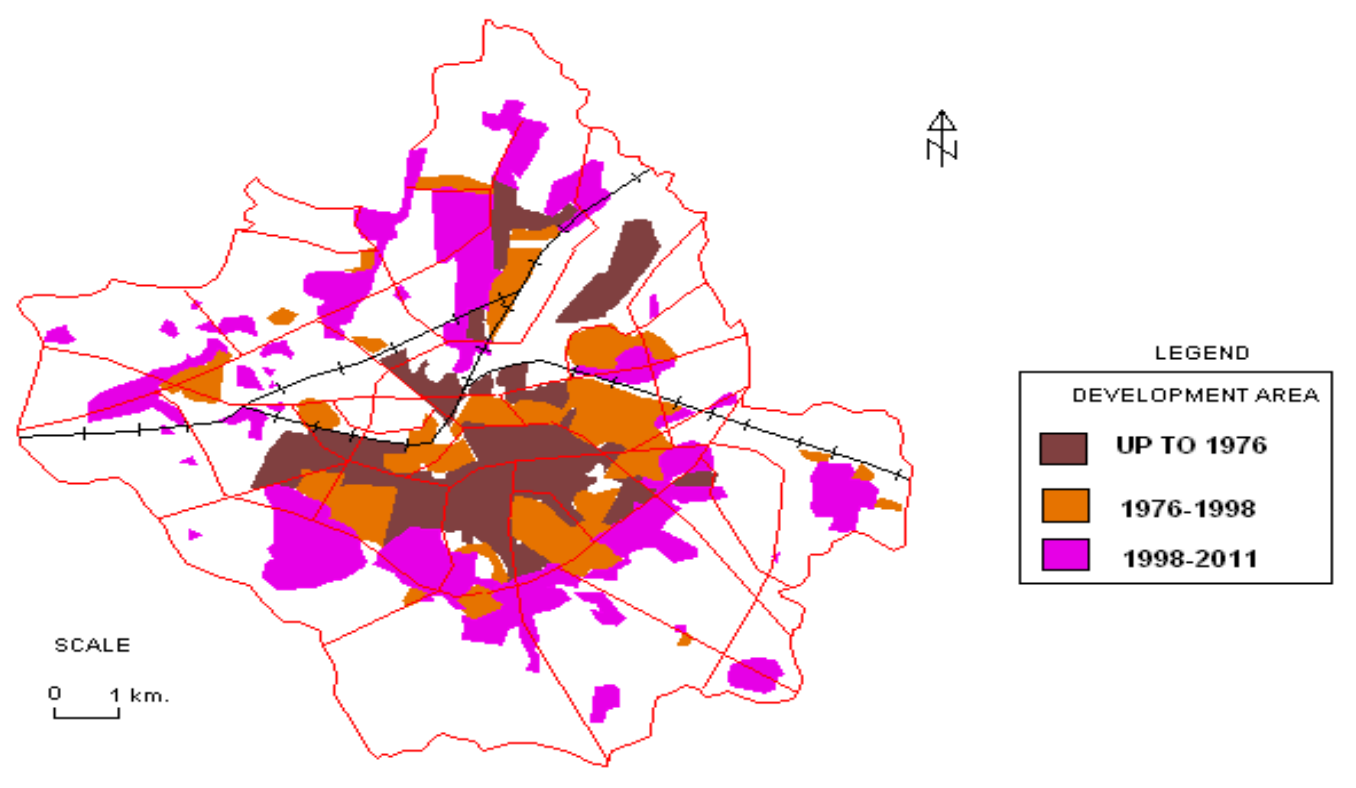

Figure no 4: Showing the Changing Pattern of Urban Sprawl Areas in Raipur City

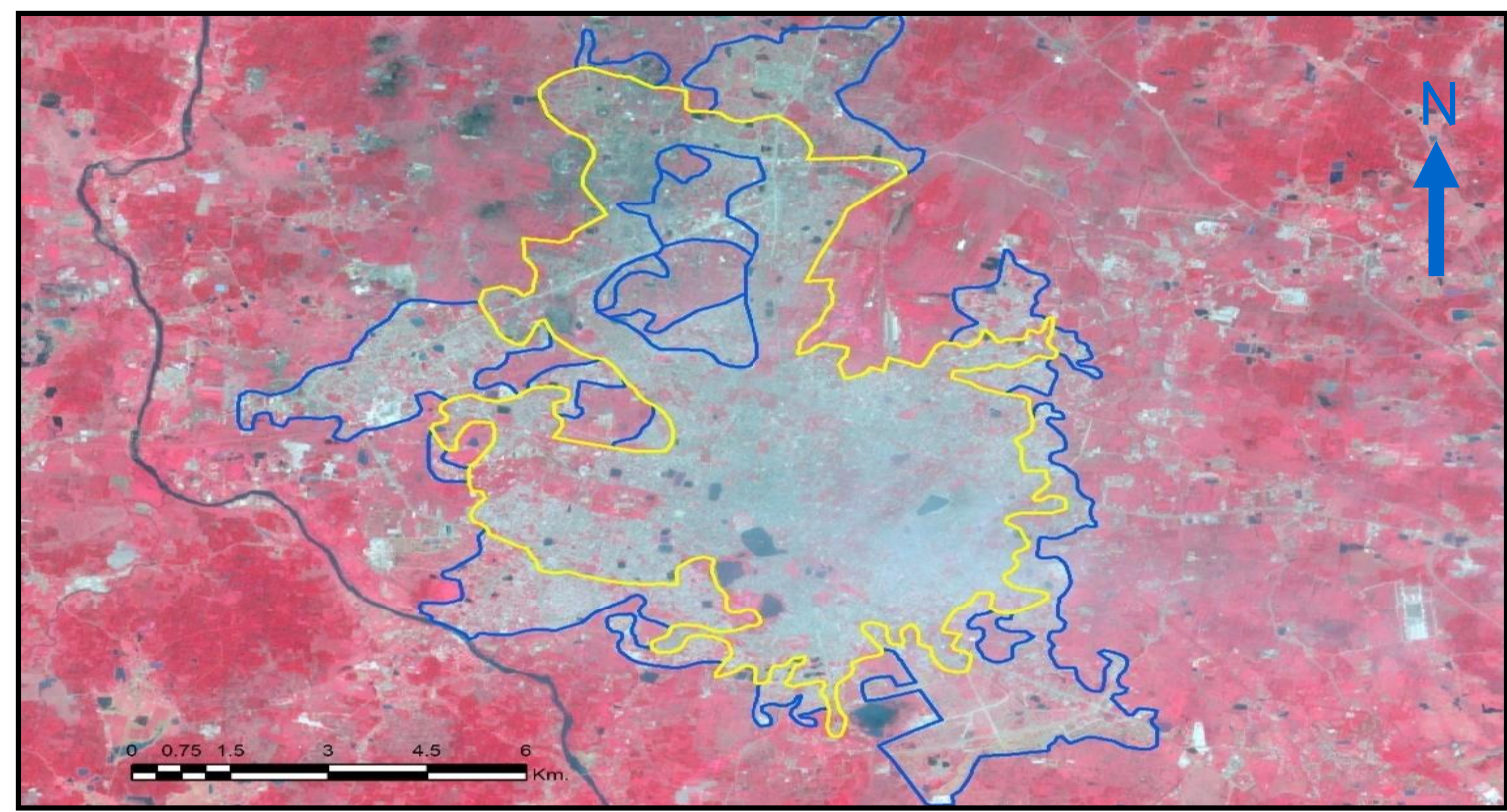

Figure no 5: Showing the Change Detection of Urban Sprawl Boundary in Raipur city

(from 2001 to 2018) 


\section{RJ and AKS}

\section{Change Detection of Urban Sprawl Boundary in}

Raipur city (from 2001 to 2018): The figure no.5 Showing that, Urban sprawl is a remarkable concentrated with particular reference to the growth of a Raipur city from C.B.D. towards fringe areas with rapidly expansion of the geographic extent of the study area which characterized by low density residential housing and single use of zoning. The expanding of urban sprawl areas of Raipur city is centrifugal in nature. The main findings of this research paper are that, the positive relationship is found between urban sprawl and emerging urban land use pattern in Raipur city. The expanding of study area is very fast in almost in all direction from city centre and it is observed that its urban sprawl areas increased continuously day by day due to rapid growth of urban population.

\section{Impact of Urban Sprawl on Urbanization in Raipur} city: Urbanization of a city is refers to the gradual increase in the proportion of people living in urban areas. With particular reference to urban morphological studies, the impact of urban sprawl on urbanization in Raipur city is a rapid and holistic transformation of human social roots on a global scale, whereby predominantly fringe areas of Raipur city is being rapidly replaced by urban regions. Urban sprawl plays a significance role for the growth of urbanization of Raipur city. Raipur city has recently got the administrative functions and urban municipal corporation areas expanding very fast in almost all direction from city centre due to impact of urban sprawl. The development of urban sprawl areas and its positive impact on urbanization are mainly caused by -

(i) Natural population growth: Raipur is a fast growing capital city of Chhattisgarh state is a bifunctional (Commercial and Industrial) city attracting the peoples for business, trade, labour and education. Natural population growth of a Raipur city is rapidly increased day by day.

(ii) Healthy urban environment: The Raipur city is spreading outside to accommodate the rapidly growing population by encroaching urban fertile land,

\section{Original article}

water bodies and vegetation; dangerous trends in the future for urban citizens, to make city healthier a proper support is necessary.

(iii) Employment opportunities: Employment opportunities are very high in Raipur city, due to these phenomena the most of the peoples are coming from rural to urban.

(iv) Immigration of people: Immigration of peoples is remarkable concentrated in Raipur city due to healthy urban environment, employment opportunities, and education opportunities etc.

(v) A good network of transport system: Development of a good network of transport system is responsible for the expanding of urban sprawl areas which is positively impact on urbanization in Raipur city as well as expanding of urban sprawl areas from C.B.D. zone towards the periphery region.

(vi) Development of Naya Raipur mission:

Construction of Naya Raipur is also responsible for the development of urban sprawl areas as well as urbanization of Raipur city.

(vii) Smart city plan: Smart city plan of Raipur city is positively impact on urbanization as well as which is lead to the development of urban sprawl areas.

The agglomeration of urban sprawl areas are mainly found in the core of the city and fringe areas of Raipur city as well as site of Naya Raipur which is now in a stage of gradual trends and many residential areas have been develop along the major roads. So, Urban sprawl areas and urbanization are highly interlinked to each other. The urban sprawl is positively impact on urbanization and emerging urban land use pattern in Raipur city.

\section{DISCUSSION}

Urban sprawl or suburban sprawl areas is the unrestricted growth of a Raipur city in many urban areas of Residential, Commercial, Public-Semipublic, Recreation, Industrial, transportation development and many roads over a large expanses of urban land use with little concern for urban planning in future. Generally air pollution is caused by urban sprawl an urbanization which is a part of development (10-12). Rapidly increasing of urban population is mainly 
RJ and AKS

responsible factor for the development of urban sprawl areas in Raipur city. Apart from the effect of increase in birth rate, migration from rural to urban place also has great impact on rapid population increase in urban area. As a result of this uncontrolled growth, problems arising from city becoming crowded direct people to live out of city center which causes urban sprawl. Apart from increasing population, increase in household income is among the factors which cause urban sprawl $(13,14)$.
Original article

Urban Sprawl Areas in Raipur City: The table no.2 \& figure no.6 showing, in Raipur city the urban sprawl areas is concentrated 25.17 sq. $\mathrm{km}$ in the study years 1971-1981, 55.03 sq.km in the study years 1981-1991, 64.29 sq.km in the study years 1991-2001, 70.47 sq.km in the study years 2001-2011, 76.84 sq.km in the study years 2011-2018. The core of the city is the Purani Basti and development of Naya Raipur which is now in a stage of gradual decay and many new colonies have sprung up which are situated along the major roads and railway line.

Table no 2: Showing the Urban Sprawl Areas of Raipur City

\begin{tabular}{|c|c|c|c|c|c|}
\hline $\begin{array}{c}\text { Study } \\
\text { Years }\end{array}$ & $1971-1981$ & $1981-1991$ & $1991-2001$ & $2001-2011$ & $2011-2018$ \\
\hline $\begin{array}{c}\text { Urban Sprawl Areas } \\
\text { (Sq. Km.) }\end{array}$ & 25.17 & $\mathbf{5 5 . 0 3}$ & $\mathbf{6 4 . 2 9}$ & $\mathbf{7 0 . 4 7}$ & $\mathbf{7 6 . 8 4}$ \\
\hline
\end{tabular}

\section{Sources: - LANDSAT Satellite Data}

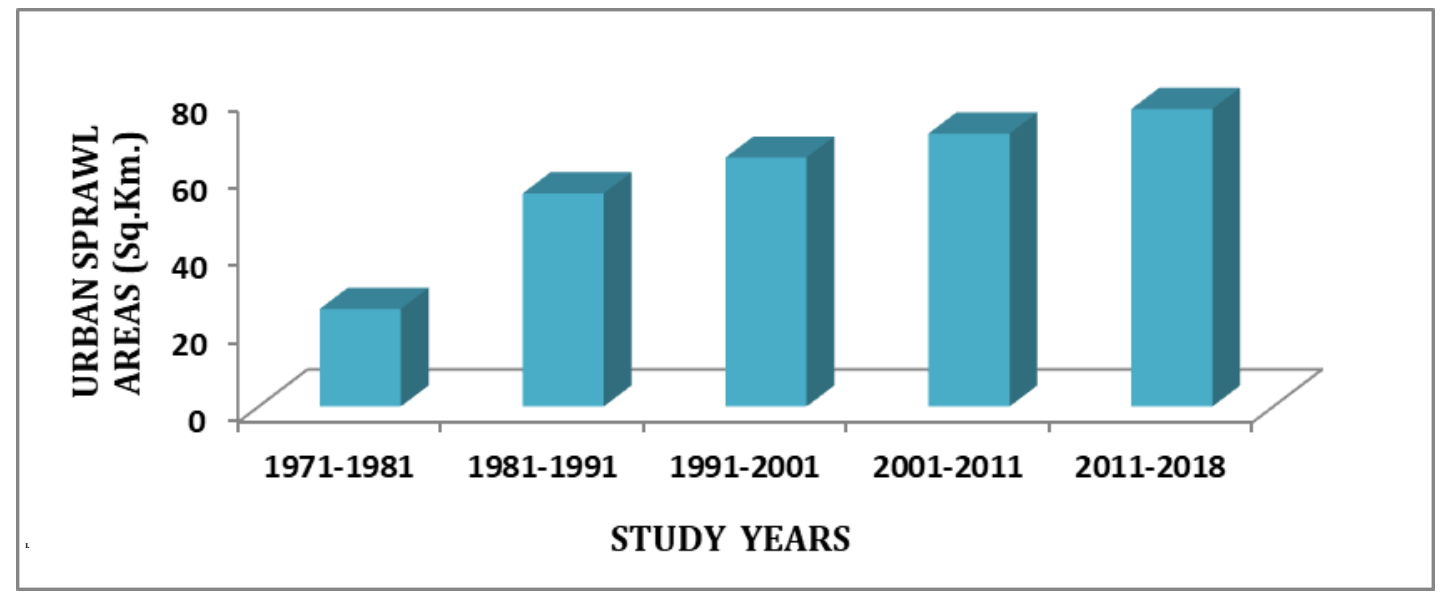

Figure no 6: Simple Bar Diagram Showing the Urban Sprawl Areas in Raipur City

\section{Urban Sprawl Boundary of Raipur City in 2001:}

The figure no. 7 Showing, According to LANDSAT Satellite Data -2001, the urban sprawl boundary of Raipur city is rapidly increased towards Kharun river as well as the urban sprawl boundary is develop along the railway lines, National Highways and major roads of Raipur city due to natural growth of urban population.

Urban Sprawl Boundary of Raipur City in 2018:

The figure no.8 Showing, According to LANDSAT

Satellite Data -2018, the development of urban sprawl areas is mainly focused on suburbs and the spreading of the Raipur city in all direction mostly and the Raipur city is spreading out from C.B.D. zones towards surrounding fringe areas due to agglomeration of rapidly growing urban population as well as continuous development of urban sprawl, healthy urban environment for citizens and immigration of peoples from rural to urban. 


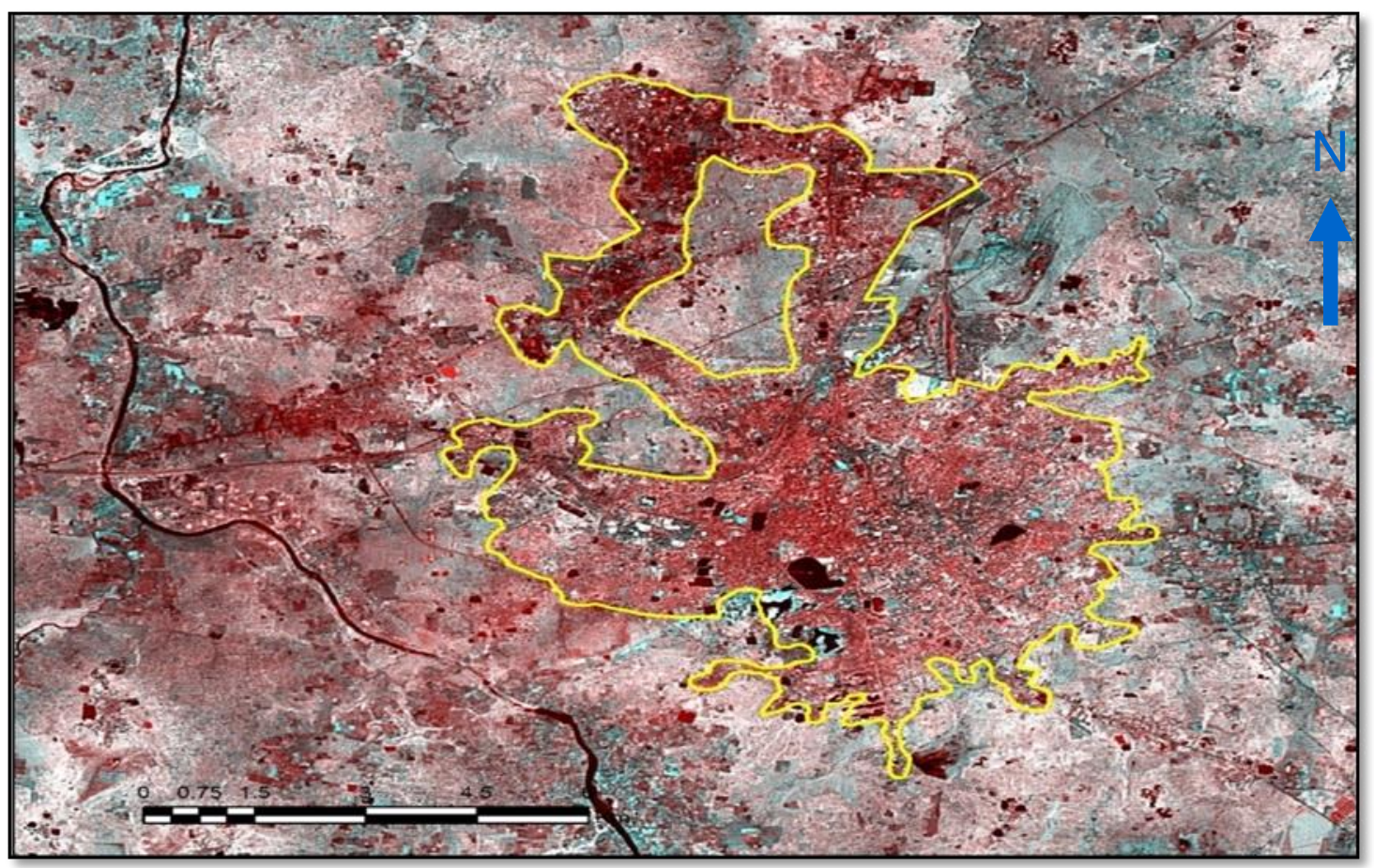

Sources: - LANDSAT Satellite imagery, 2001

Figure no 7: Showing the Urban Sprawl Boundary of Raipur City in 2001

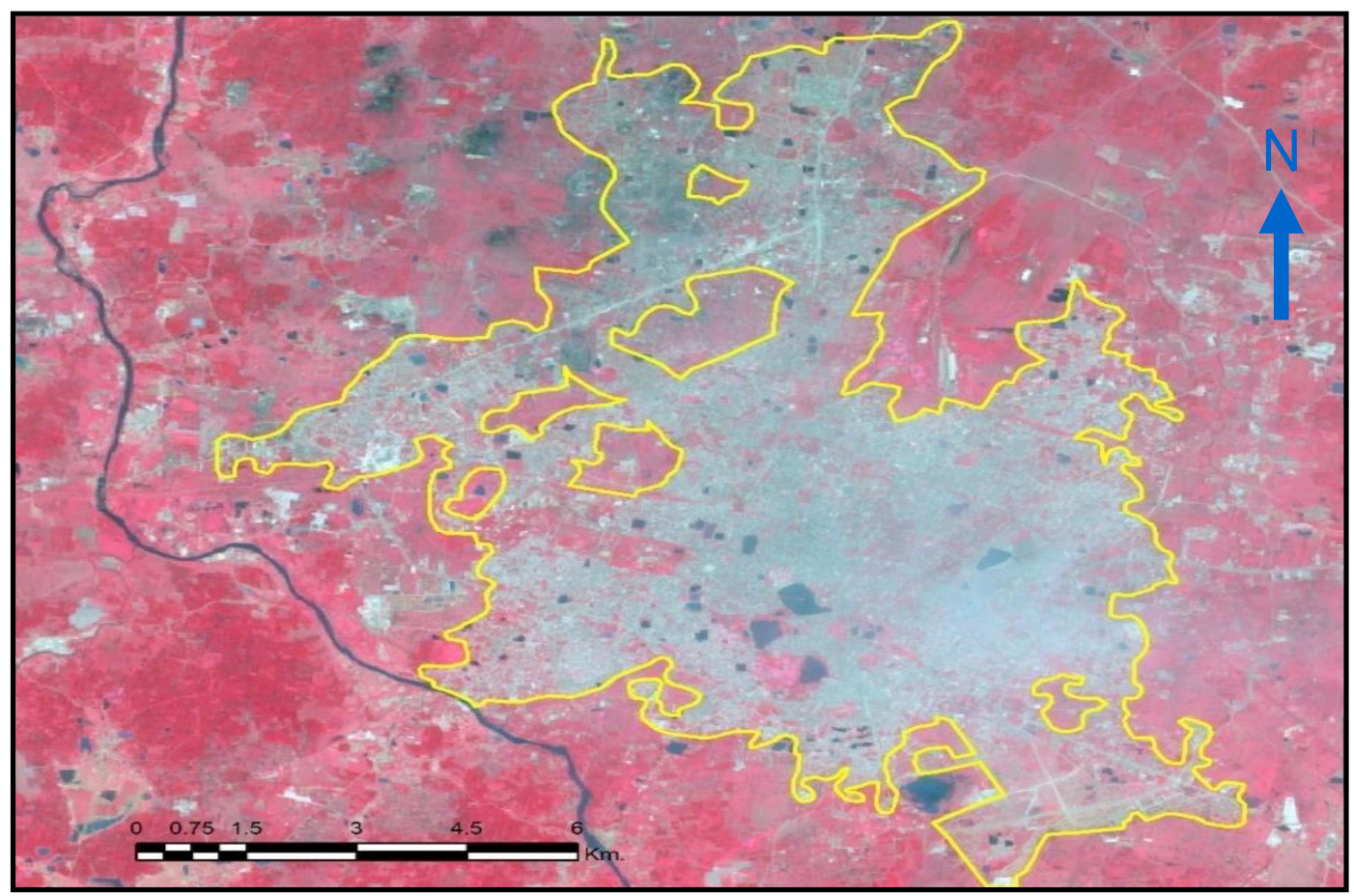

Sources: - LANDSAT Satellite imagery, 2018

Figure no 8: Showing the Urban Sprawl Boundary of Raipur City in 2018

\section{CONCLUSION}

In the reaching conclusion, this research paper critically analysis the changing scenarios of Urban Sprawl areas during different years and its positive impact on urbanization in Raipur city through the use of remote sensing and GIS techniques with the help of satellite data. The expanding of urban sprawl areas in
Raipur city is very fast in almost all direction from city centre towards periphery regions. The positive impact of urban sprawl on urbanization in Raipur city has been creates enormous social, economic and environmental changes which provide an opportunity for sustainability of urban citizens. The above study provides a positive relationship between urban sprawl 


\section{RJ and AKS}

and its impact on Urbanization for better estimation of urban growth as well as increasing population and which also lead to suitable planning strategies to counter the undesirable consequences of urban sprawl on the urbanized land use in Raipur city.

\section{ACKNOWLEDGEMENT}

We are sincerely our heartfelt gratitude to the members of town and country planning department and department of Municipal Corporation, Raipur City (Chhattisgarh State) for their kind helping hand and to provide the relevant information about this present research work until the preparation of research paper and also express our deep sense of thankfulness to the members of Chhattisgarh council of science and technology department, Raipur (Chhattisgarh State) for the guidelines of handling the satellite data as well as preparation of change detection map of the study area.

\section{CONFLICT OF INTEREST}

There is no conflict of interest in this present research paper. This research work is not a part of any other studies and it is our original work.

\section{REFERENCES}

1. Bhat PA, Shafiq MU, Mir AA, Ahmed P. Urban sprawl and its impact on landuse/land cover dynamics of Dehradun City, India. International Journal of Sustainable Built Environment. 2017; 6: 513-521.

2. Mishra RP. Million cities of India. New Delhi, Vikas Publishing House Private Limited. 1978; pp. 1- 415.

3. Jarah SHA, Zhou B, Abdullah RJ, Lu Y, Yu W. Urbanization and Urban Sprawl Issues in City Structure: A Case of the Sulaymaniah Iraqi Kurdistan Region. Sustainability. 2019; 11(485): 1-21.

4. Barnes K, Morgan J, Roberge M, Lowe S. Sprawl development: Its Patterns, Consequences and measurement. New Delhi, John Willey and Sons Publishing. 2001; pp.1-25.

\section{Original article}

5. Shao Z, Sumari NS, Portnov A, Ujoh F , Musakwa W, Mandela PJ. Urban Sprawl and Its Impact on Sustainable Urban Development: A Combination of Remote Sensing and Social Media Data. Geo-spatial Information Science. 2020 July 28; 1-15.

6. Rosni NA, Noor NM. A Review of Literature on Urban Sprawl: Assessment of Factors and Causes. Journal of Architecture, Planning \& Construction Management. 2016; 6(1): 12-35.

7. Epstein J, Payne K, Kramer E. Techniques for mapping suburban Sprawl. Photogrammetric engineering \& remote sensing. 2002 September; 63(9): 913-918.

8. Batty M, Xie Y, Sun Z. The Dynamics of Urban Sprawl. London, Arnold-Heinemann Publishers. 1999 November; 1(36): ISSN- 1467-1298.

9. Veerannachari V, Chendrayudu N. Dynamics of Land use in Kurnodi District of Andhra Pradesh using GIS. National Geographical Journal of India. 2012 March; 58(1): 37-46.

10. Dubey P, Kumar MD. Urban Sprawl and Its Impact on Urban Environment. IOSR Journal of Mechanical and Civil Engineering (IOSR-JMCE). 2013 (Nov. - Dec.); 9(5): 26-31, e-ISSN: 2278-1684, p-ISSN: 2320-334X.

11. Kaushik SP, Kaur V. Urban land use analysis using GIS techniques: A Case study of Karnal City. National Geographical Journal of India. 2009 June; 55 (2): 3346.

12. Khan MS, Khan MMA. Detection of Land use/Land covers changes Using Remote Sensing and GIS: A case study of Bulandshahr District (U.P.). National Geographical Journal of India. 2012 Sept.; 58(3): 8188.

13. Karakayaci Z. The Concept of Urban Sprawl and Its Causes. The Journal of International Social Research. 2016 August; 9(45): 815-818, ISSN: 1307-9581.

14. Gupta R. Pattern of Urban Land use changes in India. The Deccan Geographer. 2012 June; 50 (1): 1-15. 